\title{
Effectiveness of Interpersonal Communication of Head of Farmer Group To Maintaining Existence Sidodadi Farmer Group
}

\author{
Agus Subhan Prasetyo ${ }^{1 *}$, Reza Safitri ${ }^{2}$, Kliwon Hidayat ${ }^{2}$ \\ ${ }^{1 *}$ Postgraduate Faculty of Agriculture, Brawijaya University, Jl. Veteran, Malang 65145, Indonesia \\ ${ }^{2}$ Department of Social Economics, Faculty of Agriculture, Brawijaya University, Jl. Veteran Malang \\ 65145, Jawa Timur, Indonesia
}

Received: 29 September 2017; Revised: 20 October 2017; Accepted: 1 December 2017

\begin{abstract}
The success of the farmer group depends on communication skills of the head of farmer group. Hence, the head of Sidodadi farmer group need a right communication to convey the information to group members. Appropriate communication will affect the members to receive a message delivered by the head of Sidodadi farmer group properly. Either communication do by the head of the Sidodadi farmer group is interpersonal communication. This research aims to describe the farmer's group effectiveness of interpersonal communication to keep Sidodadi farmers' group maintained. The analysis method that used in this research was descriptive analysis. The result of this research shows that interpersonal communication the head of Sidodadi farmer group has been effective. Effectiveness of interpersonal communication the head of Sidodadi farmer group can be seen from the attitude of the head of Sidodadi farmer group such as open attitude, empathy attitude, support attitude, positive attitude and equality attitude. With the effectiveness of interpersonal communication, the head of the farmer group made the existence of head of Sidodadi farmer group to be maintained.
\end{abstract}

Keywords: effectiveness of interpersonal communication; head of farmer group; existence

\section{How to cite:}

Prasetyo, A. S., Safitri, R., \& Hidayat, K. (2017). Effectiveness of Interpersonal Communication of Head of Farmer Group To Maintaining Existence Sidodadi Farmer Group. HABITAT, 28(3), 99-105. https://doi.org/10.21776/ub.habitat.2017.028.3.14

\section{Introduction}

The success of a government program depends on the synergistic role of farmer groups with the extension worker to improve the welfare of the members and their family. The farmer group cannot work dynamically without the direction of the leader of the farmer group. The leader should be able to play the role of an Opinion Leader. Opinion Leader will help the group members to understand, assess and implement the government program effectively. Holding a discussion and finding the problem solving can help speed up the farmer group to achieve common goals. Therefore, the leader of the farmer group should put the interest of the group above his personal interest.

The leader as the opinion leader should understand the importance of communication in his farmer group activities. According to (Rogers,

*Corresponding Author:

E-mail: setyo.subhan@gmail.com
1969) communication has a very close relationship with leadership, it can be said that there is no leadership without communication. Basically, communication has a close relationship with social interaction between individuals. Communication has a relation with sharing information, knowledge, ideas or feelings. Hence, regular farmer group activity should be a forum for the leader to share the information with the members. Simple, organized, and coherent delivery of information can help the farmer group to understand the message conveyed by the leader. Therefore, the leader should be able to communicate effectively.

For example, the leader of Sidodadi farmer group in Junrejo Village Batu City who has implemented effective two-way communication such as interpersonal communication. (Afriyadi, 2015) explains that interpersonal communication is a communication process that takes place between two people facing each other. Interpersonal communication in the Sidodadi farmer group involves all of the members to 
discuss and express their individual opinion in the formal forum amicably. The discussion is selected to provide equal free speech opportunity and minimize disputes among the members.

The success of interpersonal communication is capable of creating a positive relationship with others effectively. According to (Risyart, 2011) effective interpersonal communication from humanistic point of view requires openness, empathy, supportive, positive and equality attitude. The purpose of having these attitudes is to improve the liveliness of the members of Sidodadi farmer group. Hence, maintaining the existence of Sidodadi farmer group and supporting the members to be more prosperous.

Based on the above descriptions, the problem of this research has been formulated that is 'how the effectiveness of the leader in maintaining the existence of Sidodadi farmer group?'

This research will describe and analyze the obstacles faced by the leader of the farmer group. The obstacles are faced when implementing the communication strategy of the leader. The research will focus on the effectiveness of the leader in maintaining the existence of Sidodadi farmer group.

\section{Research Method}

\subsection{Site and Farmer Group Determination}

Research site determination is conducted purposively at Junrejo Village Junrejo District Batu City East Java Province. The farmer group that has been selected is Sidodadi farmer group. According to the extension worker, Sidodadi farmer group located in Junrejo Village is a very dynamic farmer group. The leader of the group and its active members participate in the implementation of the program given by the government. The Sidodadi farmer group in Junrejo Village has succeeded in running the program.

\subsection{Determination of Informant}

In this research, the subject of the research is the informant that will give various information during the process of the research. The determination of first and next informant is conducted purposively. The informant in this research amounted to 6 informants consisting of 1 Field Agricultural Extension (PPL), 1 leader, 1 secretary, 1 treasurer and 2 members of Sidodadi farmer group.

\subsection{Data collection technique}

Data collection methods used in this research are an in-depth interview, observation, and documentation. Documentation data collection is divided into two namely written and visual documentations.

\subsection{Data analysis}

Analysis used in this research is descriptive analysis to describe the effectiveness of interpersonal communication of the leader of farmer group in maintaining the existence of Sidodadi farmer group. Descriptive analysis is an analysis to expose the field situation in the form of sentences or words. These sentences will be able to describe a situation, phenomenon, and fact in the field naturally. The situation will be descripted as it is and in normal situation with being manipulated by its situation and condition (Arikunto, 2002).

\section{Results and Discussion}

\subsection{Interpersonal Communication of Sidodadi Farmer Group}

The activity of communication interpersonal is a daily activity that cannot be separated by the life of the leader, especially the leader's communication with the members of farmer group. Interpersonal communication of the leader of Sidodadi farmer group with its members is very dominant. The reason is that the leader and the members live close to each other physically and socially. Interpersonal communication between the leader and the members of Sidodadi farmer group often occur in the neighborhood where they live both in the field and at home.

Good interpersonal communication skills are needed by the leader in order to maintain the existence of Sidodadi farmer group. In the farmer group activities, the leader always communicates with the members of farmer group and extension worker. The following is an explanation of the interpersonal communication of Sidodadi farmer group.

\subsection{Interpersonal Communication between the Leader of Farmer Group with the Members}

Interpersonal communication of the leader with the members of Sidodadi farmer group is necessary. It is believed that interpersonal 
communication will be able to straddle the leader and members of Sidodadi farmer group to avoid misunderstanding. Interpersonal communication will make Sidodadi farmer group more productive. Eventually, they will be able to achieve the purpose of the Sidodadi farmer group. The purposes are improving the liveliness of the members, maintaining the existence of the Sidodadi farmer group, and creating a prosperous life for the members. Sidodadi farmer group has a role as the communication channel to mutually carry out discussion and find the solution to problems. The problems between members or the leader with the members of farmer group can be solved through this means. The problems faced by the Sidodadi farmer group can be solved by sharing thoughts or information on the agricultural business run by its members.

Interpersonal communication done by the leader with the members of Sidodadi farmer group has run well. According to (Tubbs \& Moss, 2000), interpersonal communication will run well due to the approach emphasizing the concept of sharing experience. Hence, someone's action is conducted within his capacity as the communicator. This is what has happened in the Sidodadi farmer group. The leader and its members share their experience in solving the problems in the agricultural business run by the members of Sidodadi farmer group.

As expressed by (Kusumastuti, 2015), one of the ways to understand the human behavior is by observing and understanding its social relationships. One of the relationships can be created with the process of interpersonal communication. This phenomenon has occurred in the Sidodadi farmer group. The leader of the group has a close relationship with the members. The leader lets the members participate in the meeting and communicate actively with other members. The members also receive valuable information from the leader and share it with other members extensively. The leader and members of Sidodadi farmer group understand and support each other well to maintain the existence of Sidodadi farmer group and improve their agricultural business.

\subsection{Interpersonal Communication between the Leader and Extension Worker}

The interaction of the leader of Sidodadi farmer group in Junrejo Village with Field Agricultural Extension (PPL) shows an interpersonal communication between the parties. Interpersonal communication between the parties is conducted during the meeting with the members. This activity is done once a month. However, the leader always tries to communicate with the extension worker regarding the problem he is currently facing by phone. Interpersonal communication between the leader and the extension worker is seen as less effective. The reason is that the outreach done by the extension worker is less intensive.

According to the (Kementerian Pertanian, 2008), extension worker should conduct more than 60 times visits in conducting the outreach in the form of face to face interaction individually or collectively. It is expected that through 60 times face to face interaction with the farmers, the extension worker can meet the farmers at least 5 times every month. The research results show different thing because the extension worker only does the outreach once a month during the meeting of Sidodadi farmer group. Sometimes, the extension worker will skip the meeting if he or she has another urgent matter to do. This issue has forced the leader to discuss and solve the problems only with the members of Sidodadi farmer group most of the time. As stated by the leader of Sidodadi farmer group:

"the extension worker only meets the farmers during the meeting. If there is a lot more important matter from Batu City office and they ask him to come, he will go right away. If there is a problem, he will also call right away".

Based on the statement of the leader, it can be seen that the intensity of outreach in Junwatu Sub-Village Junrejo Village is less communicative. Especially the visit to the leader and members of Sidodadi farmer group. In addition, the outreach is not properly and timely managed. Thus, the communication between the leader and extension worker is mostly done by phone. The extension worker of Junwatu SubVillage Junrejo Village should try better communication approach and visit the farmer every day. By doing this, the extension worker will be able to understand better the problems faced by the farmers and their needs. Based on the extension worker assessment indicator issued by the Ministry of Agriculture, the extension worker of Junwatu Sub-Village Junrejo Village should do at least 5 times face to face meeting with the Sidodadi farmer group in conducting the outreach in the form of face to face interaction individually or collectively. 


\subsection{Effectiveness Communication of the Leader of Sidodadi Group \\ of Interpersonal}

Interpersonal communication is a form of behavior that can change from effective to very ineffective. Interpersonal communication can be effective or ineffective depending on how the process of interpersonal communication itself. Effective interpersonal communication can be created through the agreement of information and the quality of the relationship built in daily life both in the community and group. Effective interpersonal communication can make a positive relationship with others. According to (De Vito, 2001) effective interpersonal communication can be seen from the humanistic perspective which requires openness, empathy, supportive, positive and equality attitude. Effective interpersonal communication of the leader of Sidodadi farmer group in Junwatu Sub-Village Junrejo Village Junrejo District is explained as follows:

\section{1) Openness}

According to (Rakhmat, 2012), openness has a huge influence in developing effective interpersonal communication. Openness to interact with others show a willingness to respond others and to open up. According to (Kumar, 2000), openness is the willingness to happily respond information received in facing interpersonal relationship. From the research results, the leader of Sidodadi farmer group is very open shown by his attitude. The leader is open to the members of Sidodadi farmer group regarding all of the information obtained by the leader during his leadership.

Openness is also shown through the delivery of all information such as the funding from the government of Batu City, agricultural tools aids, or the announcement of new agenda and events held by the agricultural office or the government of Batu City. In addition, the knowledge that has been obtained by the leader during workshop or outreach is shared during the meeting of Sidodadi farmer group. However, the leader never shares the information with the members individually. The leader often waits until the meeting to share the information. As expressed by Mr. Kastanu as the leader of Sidodadi farmer group:

"I usually share information from the extension worker directly. For example, if I'm invited on a certain date by the government regarding a certain issue, I will inform the members right away. The information is delivered during the meeting on the date of 25 that month. For example, the meeting in the government office is held on 27 which is after the farmer group monthly meeting, thus I will share the information on 25 next month. I will note the issues and share it with the members".

As expressed by the extension worker in Junrejo Village:

"Mr. Kastanu as the Leader of Sidodadi Farmer Group is very honest. He is very professional during the outreach. Mr. Kastanu always tries to find additional information from various sources when the group faces a problem and he will try to solve it".

Based on the statement made by the extension worker in Junrejo village, the leader always tries to find additional information from various sources when the members of Sidodadi farmer group faces agricultural problems. In addition, both the leader and members are not hesitant to share their experience and knowledge to solve the problem faced by the agricultural business actors in the Sidodadi farmer group.

\section{2) Empathy}

According to (Risyart, 2009), Empathy is an attitude that should be embedded in each individual's heart. The presence of empathy will show that human is an individual creature with feelings. Eventually, it will encourage us to be a better human who is beneficial to others. By understanding what others feel or experience, placing oneself in someone else's role or position, trying to see and feel other people life. Empathy in this research is the leader's ability to position himself in the situation and condition faced by the members of Sidodadi farmer group in Junwatu Sub-Village Junrejo Village.

From the research results, it can be seen that the leader of Sidodadi farmer group has empathy. His empathy is shown through the openness for all opinions and complaints from the members of the group. The leader usually gives his opinion and suggestion during the meeting and all of the members are given the chance to complain regarding the problem they can't solve. Thus, the problem is solved through discussion. This is in accordance with (Kumar, 2000) suggestion that empathy is someone's willingness to understand someone else's experience from his perspective and eyes. As stated by the leader of Sidodadi farmer group: 
"if there is a problem in the group, especially about agricultural. Everyone will tell me and I will try to find the solution through negotiation"

From the research, it can be concluded that the leader of Sidodadi farmer group has empathy. Good empathy is derived from the sense of kinship preserved well in Junwatu Sub-Village Junrejo Village. This is proven by the people who like to help each other and mutual support between the leader and members of farmer group. The leader always accommodates each group member's complaints. The complaints from the members are different from one and another, either the complaint about the agricultural business or beyond. The leader gives solution in the form of support to encourage them to be patient and persistent in facing the problem. The leader also gives useful input for them. If the problem faced by the members is related to agricultural, he will try to solve it based on his experience from running the agricultural business or by joining the activity conducted by Batu City government service and Batu City Agricultural office.

\section{3) Supportive}

According to (De Vito, 2001), effective interpersonal communication is complemented with a supportive attitude. Open and empathetic interpersonal communication does not occur in the unfavorable atmosphere. The leader of the farmer group has this supportive attitude. The leader also performs his duty as the leader and responsible for the mandate he has to carry out. The leader's supportive attitude is also shown when the leader always shares any information from the government program or agenda. He also shares any problem related to agricultural with the members of the group. If it is not possible to wait until the date of group regular meeting, the leader will come to every member's house to share the important news. As stated by the leader below:

"I always try to be responsible and honest when carrying out my duty. If we find a problem we will try to solve it through negotiation for consensus. The problem will be delivered during the meeting and if it is urgent I will visit each member's house".

The purpose of is to make sure that the group will run well and become more advanced. In addition, the leader is always trying to be professional in carrying out his duty as the leader of Sidodadi farmer group. He also performs a problem-oriented action and tries to solve the problem through negotiation for consensus. This is in accordance with (Rakhmat, 2012) statement that supportive attitude can reduce defensive behavior during communication. Supportive attitude does not control the problem but solves it through a problem-oriented action.

\section{4) Positive Attitude}

According to (De Vito, 2001), positive attitude is a positive outlook on oneself, others and every communication situation. Positive attitude in the effectiveness of interpersonal communication is one of the important factors in the interpersonal communication process. This part will explain the positive attitude of the leader of the farmer group in Junrejo Village.

Based on the research results conducted on the leader of Sidodadi farmer group, the leader has a positive attitude in performing interpersonal communication with the members. The leader is capable of interacting comfortably with the members of the group. The leader always shows positive outlook in his mind, thus driving the members to have positive thinking as well. This is in accordance with what has been stated by (Kumar, 2000) that in performing effective interpersonal communication someone has to have a positive outlook on himself. This will encourage other people to actively participate and create conducive communication situation for effective interaction. As stated by the leader of Sidodadi farmer group below:

"I always try to have a positive outlook during the activities in the group. If someone approaches me and tells me something, I will try to believe him. Stating the fact as it is. For me, the most important thing is to keep remaining each other without hurting their feelings".

Positive attitude owned by the leader is supported by the same and intimate working environment when interacting and building kinship between the leader and the members of Sidodadi farmer group. In addition, the leader has the same cultural background because he lives in the same area with the members. Furthermore, positive attitude owned by the leader of the group is derived from his positive outlook on himself. Hence, the members as his interaction partner feel comfortable.

\section{5) Equality}

According to (De Vito, 2001) equality attitude is a desire explicitly expressed to 
cooperate in solving a problem. Equality attitude means the same value, attitude, behavior, experience and similarity in the conversation. The research results show the same thing that the leader of the group possesses equality attitude. The leader tries to not treat one member and another differently. According to the leader, the members and he have the same right to express their opinion. The leader and the members have the same right and obligation to advance Sidodadi farmer group. Both the leader and the members should contribute to the group for the group's advancement. The research result related to the equality attitude owned by the leader is in accordance with (Kumar, 2000) statement that equality, tacit recognition that both parties appreciate each other, useful, and has something important to contribute. As expressed by the leader of Sidodadi farmer group below:

"there is no difference between the members and leader, all of the parties respect each other and accept the suggestion well".

Equality attitude owned by the leader of the group shows that the leader and its members respect each other. This can happen because they have the same cultural background and they live in the same area, making it easier for them to exchange information and to equate the meaning of the information received. In addition, the existing equality attitude is supported by good cooperation between the leader and its members in solving the agricultural problems happened at Junwatu Sub-Village Junrejo Village.

In general, it can be concluded that interpersonal communication of the leader is effective. According to (De Vito, 2001), in order to reach the effectiveness of interpersonal communication, everyone must have five aspects of the effectiveness of communication such as openness, empathy, supportive, positive and equality attitude. Table 1 below shows the illustration of the effectiveness of interpersonal communication of the leader of Sidodadi farmer group:

Based on the research results, it can be said that the leader of Sidodadi farmer group has five elements stated by (De Vito, 2001). They are openness, empathy, supportive, positive and equality attitude. The effectiveness of interpersonal communication owned by the leader of the group will encourage a positive relationship between the leader of the group and its members. Interpersonal communication of the leader is effective due to pleasing communication between them. This can be seen from the regular meeting done by the group. Both of the leader and its members are very active in the discussion to solve the problem on the members' agricultural business. The leader of the group and its members can share their experience related to their agricultural business. Interpersonal communication performed by the leader of the group and its members are very relaxed, pleasing and open. This is in accordance with (Rakhmat, 2012:116) opinion in his book entitled communication psychology. He states that interpersonal communication is effective when the communication meeting is fun for the communicant.

Table 1. The Effectiveness of Interpersonal Communication of Sidodadi Farmer Group

\begin{tabular}{ll}
\hline $\begin{array}{l}\text { Effectiveness of } \\
\text { Interpersonal } \\
\text { Communication }\end{array}$ & $\begin{array}{l}\text { Leader } \\
\text { Sidodadi } \\
\text { Farmer } \\
\text { Group }\end{array}$ \\
\hline Openness Attitude & $\checkmark$ \\
Empathy Attitude & $\checkmark$ \\
Supportive Attitude & $\checkmark$ \\
Positive Attitude & $\checkmark$ \\
Equality Attitude & $\checkmark$ \\
\hline
\end{tabular}

\section{Conclusion}

Based on the analysis results, it can be concluded that the leader of Sidodadi farmer group has performed good interpersonal communication with the members of the group and extension worker. The leader of the group has effective interpersonal communication where the effectiveness of the interpersonal communication is proven by five attitudes namely openness, empathy, supportive, positive and equality attitude.

\section{Daftar Pustaka}

Afriyadi, Ferry. (2015). Efektivitas Komunikasi Interpersonal Antara Atasan Dan Bawahan Karyawan Pt. Borneo Enterprsindo Samarinda. eJournal lmu Komunikasi, 2015, 3 (1): 362-376 ISSN 0000-0000, ejournal.ilkom.fisip-unmul.org Copyright 2015. 
Arikunto, Suharsimi. (2002). Prosedur Suatu Penelitian: Pendekatan Praktek. Rineka Cipta. Jakarta.

De Vito, Joseph A. (2001). The interpersonal Communication Book. 9th edition New York: Hunter College of the City University of New York. [terjemahan] Profesional Books, Jakarta.

Kementerian Pertanian. (2008). Perubahan Atas Keputusan Menteri Pertanian Nomor 553/Kpts/Ot.210/9/2002 Tentang Organisasi dan Tata Kerja Sekolah Tinggi Penyuluhan Pertanian Magelang. Peraturan Menteri Pertanian Nomor : 43/Permentan/Ot.140/10/2008.

Kumar A. (2000). Encyclopedia of Mass Media and Communication. Anmol Publication. New Delhi.

Kusumastuti, Ayu. (2015). Modal Sosial dan Mekanisme Adaptasi Masyarakat Pedesaan dalam Pengolahan dan Pembangunan Insfrastruktur. Jakarta. LabSosio, Pusat Kajian Sosiologi FISIP-UI. ISSN: 08528489. SK Dirjen Dikti Akreditasi Jurnal No. 80/DIKTI/Kep/2012. Masyarakat: Jurnal Sosiologi, Vol. 20, No. 1, Januari 2015:8197.

Rakhmat, Jalaluddin. (2012). Psikologi Komunikasi. Bandung: PT Remaja Rosdakarya.

Risyart A. Far-Far. (2009). Hubungan Efektivitas Komunikasi Interpersonal Dengan Perilaku Bercocok Tanam Padi Sawah (Kasus Desa Waimital Kecamatan Kairatu Kabupaten Seram Bagian Barat). Tesis Sekolah Pasca Sarjana Institut Pertanian Bogor.

Risyart A. Far-Far. (2011). Hubungan Komunikasi Interpersonal dengan Perilaku Petani dalam Bercocok Tanam Padi Sawah di Desa Wamital Kabupaten Seram Bagian Barat. Jurnal Budidaya Pertanian, Vol. 7. No 2, Desember 2011, Halaman 100-106.

Rogers, EM. (1969). Modernization among peasants: the impact of communication. New York:Holt, Rinehart and Winston, Inc.

Tubbs SL. Moss S. (2000). Human Communication: Prinsip-prinsip Dasar. Buku pertama. Pengantar; Deddy Mulyana. Bandung: Remaja Rosdakarya. 